\title{
Risk evaluation and control of EPC hydropower construction project in Vietnam
}

\author{
MAI Sy Hung ${ }^{1,}$ a , WANG Jian Qiong ${ }^{2, b}$ and VU Hong Anh ${ }^{3, c}$ \\ ${ }^{1}$ Water construction department, University of Civil Engineering, Hanoi, Vietnam 100803; School of \\ Economics and Management, Southwest Jiaotong University, Chengdu, China 610031 \\ ${ }^{2}$ School of Economics and Management, Southwest Jiaotong University, Chengdu , China 610031 \\ ${ }^{3}$ School of Economics and Management, Southwest Jiaotong University, Chengdu, China 610031 \\ a1619898230@qq.com, bqiongsi007@126.com, 554335443@qq.com
}

Keywords: Construction project, EPC hydropower construction (EPC); Risk evaluation and control; hydropower project in the form of EPC; hydropower project .

Abstract. In Vietnam, now many hydropower project adopts the EPC (engineering, procurement and construction) of the contract. However, in the implementation of these hydropower projects, the EPC general contractors are facing many difficulties, resulting in schedule delays and considerable losses . From the above mentioned issues, this research study is conducted to highlight the main risk factors in the delays of hydropower construction projects in Vietnam. The research outcomes as follows: Risk evaluation; calculating and classifying the degree of impact of each risk to the progress of the construction; presenting expert opinions to control such risks. The practical significance of this study is to ensure the timely completion of projects, benefits for the investors, and the EPC general contractors. The research employs the method of statistical calculations and risk analysis to obtain feedback from experts participating in similar projects. A feature of this research is the comprehensive use of investigative methods statistic, and analysis of the results of the conducted survey on delay risks of EPC hydropower projects in Vietnam.

\section{Research context and proposed research orientation}

\section{Research context}

The EPC contract of the hydropower projects in Vietnam is facing many difficulties due to slow progress in construction. There are numerous factors leading to slow construction progress. To identify these factors, the author analyzed the characteristics of hydropower projects combined with the opinions of experienced experts with hydropower projects in Vietnam. On this basis, hypotheses about risk models are developed. The most general characteristics of hydropower projects following the EPC in the Vietnam as follows: The use of EPC in Vietnam is relatively new, and project management is slow, leading to tardiness; At the construction sites, the people's culture standard is low, causing various difficulties; The immigration and resettlement for land withdrawal and handover for the construction contractors are complex; Hydropower equipment for the projects must be imported from abroad with complex procedures, difficult shipment, and slow assembly; These countries currently keep high inflation rates, which affect the purchase of required materials, machines, and equipment; Natural conditions such as climate, hydrology, topography, and geological conditions lead to further complications; The sub-contractors construction capacity is poor; the domestic construction technology has low productivity, and is not up to standard; The infrastructure and traffic facilities for transport are poor; machine and equipment transportation encounter many difficulties, leading to delays, etc.In recent years in Vietnam, more attention has been given to risk management of hydropower projects. For instance, Zhao Jue Long (2008) [1] studied cases of EPC hydropower projects in Vietnam, proposed risk factors, and suggested ways to minimize risks and proposed management measures. Li Wei (2012) [2], through the research of the Con River hydropower station in Vietnam, showed risks in project procurement, contract construction, material purchases, risks of delays in the project, and the increased expenses in construction.... 
In the above mentioned literature, the author found that research on risks in hydropower projects in Vietnam is still limited. With the reality of tardy construction projects and progress delays, the author deems it urgent to conduct research on risks involved in delaying the construction progress of the hydropower project using EPC in Vietnam.

\section{Proposal for project orientation}

Research on delay risks of EPC hydropower construction projects in Vietnam. Research would contribute to the monitoring of construction progress and successful implementation.

In addition, using the public information on the Internet, television, newspapers and other documents, the author carried out on-site interviews with experts and officers participating in EPC projects. On the basis of these opinions, the author hypothesized the risk factors, and calculated statistical with SPSS and AMOS software to analyze and complete the objective.

The structure of this research includes three main parts: (1)The risk hypothesis and the impacts of risks on construction schedule; (2)Calculation and inspection of risk, Risk evaluation; (3)Controlling and limiting risks.

\section{Risk evaluation of EPC hydropower construction project in Vietnam}

\section{Risk variables and risk model selection}

\section{1)Risk variables}

The risk variables system is built utilizing mainly the analysis of previous research and consulting experts. A comprehensive analysis of the current research results and expert opinions helped to form the questions. The benefit being that the experiences and knowledge of the experts assists in the selection of reasonable questions.

Through the analysis of information and consultation of experts' opinions, we summarize the characteristics of the hidden risks leading to delays in the construction progress of the hydropower projects. Based on these characteristics, the main reasons leading to the construction progress delays can be divided into the following groups: Risk from natural conditions and social environment (B1), Risk from management (B2), Risk from technology (B3), Risk from contracts (B4), Risk from economy (B5), Risk from politics and law (B6), Risks from EPC general contractors (B7). Below is systematic table of risk factors.

Table 1: Hypothesis of risk groups:

\begin{tabular}{|c|c|c|}
\hline $\begin{array}{l}\text { Objective for } \\
\text { evaluation }\end{array}$ & $\begin{array}{l}\text { Risk group level } 1 \\
\text { (Hidden risk cause } \\
\text { variables) }\end{array}$ & $\begin{array}{c}\text { Risks level } 2 \\
\text { (Hypothesized risk variables) }\end{array}$ \\
\hline \multirow{5}{*}{$\begin{array}{l}\text { Delaying the } \\
\text { construction } \\
\text { progress }\end{array}$} & $\begin{array}{l}\text { Risk from natural } \\
\text { conditions and social } \\
\text { environment (B1) }\end{array}$ & $\begin{array}{l}\text { Ethnic groups and religions ( b1.1) } \\
\text { Geology, topography, and hydrography (b1.2) } \\
\text { Transportation outside of the construction site (b1.3) } \\
\text { Safety and security (b1.4) }\end{array}$ \\
\hline & $\begin{array}{l}\text { Risk from management } \\
\text { (B2) }\end{array}$ & $\begin{array}{l}\text { Poor progress management (b2.1) } \\
\text { Poor quality work requiring repair (b2.2) } \\
\text { Construction projects monitoring team ( b2.3) } \\
\text { Construction safety (b2.4) } \\
\text { Inharmonious management among the EPC general contractors (b6.5) }\end{array}$ \\
\hline & $\begin{array}{l}\text { Risk from techniques } \\
\text { (B3) }\end{array}$ & $\begin{array}{l}\text { Technical design (b3.1) } \\
\text { Negative survey data (b3.2) } \\
\text { Construction drawings (b3.3) } \\
\text { Inspection of technical and drawings design (3.4) } \\
\end{array}$ \\
\hline & $\begin{array}{l}\text { Risk from contracts } \\
\text { (B4) }\end{array}$ & $\begin{array}{l}\text { Uncertain and unclear contract terms (b4.1) } \\
\text { Unfair contract terms (b4.2) } \\
\text { Transportation outside the construction site (b4.3) } \\
\text { Second language contracts with misleading clauses (b4.4) }\end{array}$ \\
\hline & $\begin{array}{l}\text { Risk from economy } \\
\text { (B5) }\end{array}$ & $\begin{array}{l}\text { Finances of the investor (b5.1) } \\
\text { Interest rate fluctuations (b5.2) } \\
\text { Risks on Inflation (b5.3) } \\
\text { Financial capacity of EPC general contractors (b5.4) }\end{array}$ \\
\hline
\end{tabular}




\begin{tabular}{|c|c|l|}
\hline & $\begin{array}{c}\text { Risk from politics and } \\
\text { law } \\
\text { (B6) }\end{array}$ & $\begin{array}{l}\text { The relationship of investor, general contractor with the authority and } \\
\text { relevant departments (b6.1) } \\
\text { Laws and regulations of the management agencies ( b6.2) } \\
\text { Regional political change (b6.3) }\end{array}$ \\
\cline { 2 - 3 } & $\begin{array}{c}\text { Reneral contractors } \\
\text { (B7) }\end{array}$ & $\begin{array}{l}\text { Purchasing materials, supplies, equipment and machines (b7.1) } \\
\text { Difficulties with sub-contractors (b7.2) } \\
\text { Equipment installation and commissioning (b7.3) } \\
\text { Poor construction from the EPC general contractors (b7.4) }\end{array}$ \\
\cline { 2 - 4 } & $\begin{array}{c}\text { Consequences of the } \\
\text { risk factors(B8) }\end{array}$ & $\begin{array}{l}\text { Prolong the construction progress (b8.1) } \\
\text { Increase in construction costs (b8.2) }\end{array}$ \\
\hline
\end{tabular}

\section{2)Selection of variables for risk calculation models}

Based on the above hypothesis of risks, the author summarized and proposed the hypothesis of the risk model affecting progress as follows: (shown in Fig. 1)

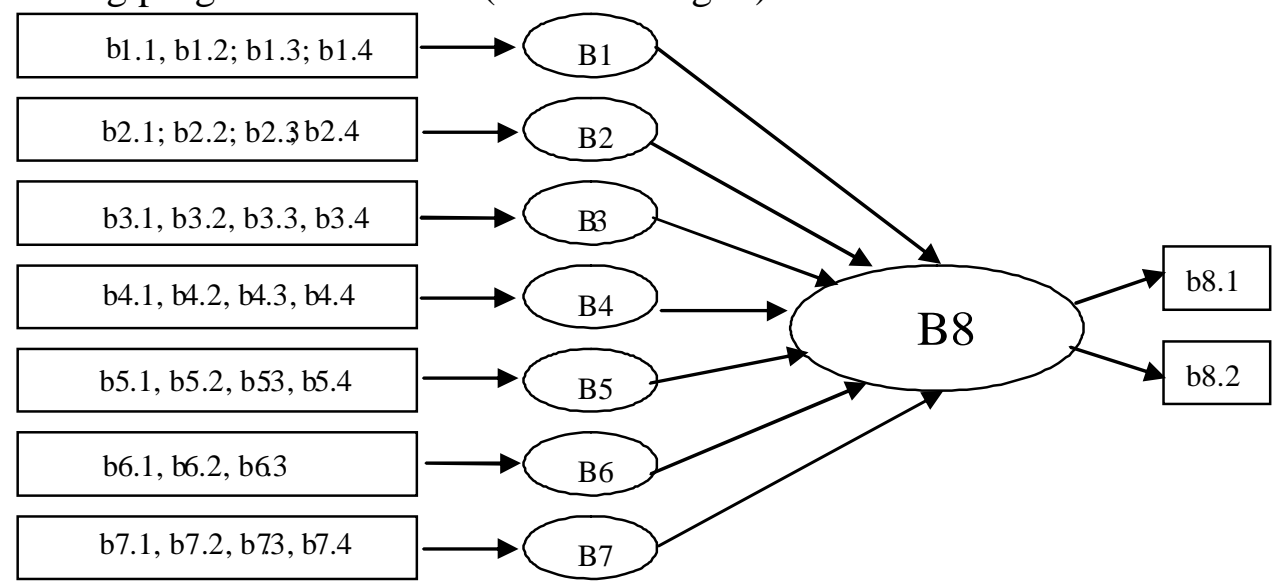

Fig 1: specifies the assumptions of the risk system model affecting the progress

\section{Calculation and verification of the hypothesis model}

\section{1) Data and supporting software}

From the hypothesis of risks in Table 2, the author did an investigation using slips with 5 levels of risk assessment as follows:

Table 2: Investigation using slips with 5 levels of risk assessmen

\begin{tabular}{|c|c|c|c|c|c|}
\hline \multirow{2}{*}{ 1: Risk factors and risk consequences } & \multicolumn{3}{|c|}{ Impact level of construction progress delays } \\
\cline { 2 - 6 } & $\begin{array}{c}\text { Low } \\
(1)\end{array}$ & $\begin{array}{c}\text { Rather } \\
\text { low(2) }\end{array}$ & Medium (3) & $\begin{array}{c}\text { High } \\
(4)\end{array}$ & $\begin{array}{c}\text { Very high } \\
(5)\end{array}$ \\
\hline Risk factors of risk group at level 2 & & & & & \\
\hline $\begin{array}{c}\text { 2: Consequences of risk factors } \\
\begin{array}{l}\text { Prolong the construction progress. Increase in } \\
\text { construction costs }\end{array}\end{array}$ & $<10 \%$ & $10-20 \%$ & $20-30 \%$ & $\begin{array}{c}30-40 \\
\%\end{array}$ & $>40 \%$ \\
\hline
\end{tabular}

Based on EPC hydropower projects in Viet nam. To find out the reasons in delay of above projects the authors adopted questionnaire method.

To ensure the reliability of the questionnaire, The author then met with experts in these fields: investors, design consultants, EPC general contractors and subcontractors. These experts have been, or are currently involved in hydropower projects with EPC in the region. The questions distributed, surveyed, and collected are in following table 3:

Table 3: The questions distributed, surveyed and collected

\begin{tabular}{|c|c|c|c|}
\hline $\begin{array}{c}\text { Number of distributed } \\
\text { questionnaires }\end{array}$ & $\begin{array}{c}\text { Number of collected } \\
\text { questionnaires }\end{array}$ & $\begin{array}{c}\text { Number of proper } \\
\text { questionnaires }\end{array}$ & $\begin{array}{c}\text { Number of questionnaires } \\
\text { using analysis }\end{array}$ \\
\hline 280 & 262 & 255 & 255 \\
\hline
\end{tabular}

Based on the above data, the author used statistical methods to verify the accuracy of the risk variables model hypothesis based on necessary evaluation criteria such as: Alpha Cronbach 
coefficient to determine the reliability of the question, the discovery of factors, and verification of those factors. The author used SPSS and AMOS software to analyze and verify the above evaluation criteria.

\section{2)Verification results}

Calculate the Cronbach's Alpha reliability coefficient: The Cronbach's Alpha coefficient value $(\alpha)$ in the interval from $0-1$, if $\alpha<0.6$ is insufficient reliability, $0.6<\alpha<0.8$ is sufficient reliability, $0.8<\alpha<1$ is high reliability. In the survey data for research, we can use $\alpha>0.6$ achieved reliability, can use for analysis, (Hair J F, Anderson R E 1998)[5]; (Slater 1995)[6].

Using SPSS software to conduct the calculations and testing, the author eliminated the variables with "Corrected Item-Total Correlation" $<0.3$. The Cronbach's Alpha was then calculated, providing corresponding results to the factors groups as follows: (shown in the Table 4)

Table 4:Cronbach's Alpha

\begin{tabular}{|l|l|l|}
\hline \multicolumn{1}{|c|}{ Group of hidden cause variables } & \multicolumn{1}{|c|}{$\begin{array}{c}\text { The } \\
\text { assumption of risk } \\
\text { variables }\end{array}$} & $\begin{array}{c}\text { Cronbach } \\
\text { 's Alpha }\end{array}$ \\
\hline $\begin{array}{l}\text { Risk from natural conditions and social environment } \\
\text { (B1) }\end{array}$ & $\mathrm{b} 1.2 ; \mathrm{b} 1.3$ & 0.791 \\
\hline Risk from management (B2) & $\mathrm{b} 2.1 ; \mathrm{b} 2.3$ & 0.723 \\
\hline Risk from techniques (B3) & $\mathrm{b} 3.1 ; \mathrm{b} 3.2 ; \mathrm{b} 3.3 ; \mathrm{b} 3.4$ & 0.724 \\
\hline Risk from contracts (B4) & $\mathrm{b} 4.1 ; \mathrm{b} 4.3$ & 0.818 \\
\hline Risk from economy (B5) & $\mathrm{b} 5.1 ; \mathrm{b} 5.3 ; \mathrm{b} 5.4$ & 0.660 \\
\hline Risk from politics and law (B6) & $\mathrm{b} 6.1 ; \mathrm{b} 6.2$ & 0.802 \\
\hline Risk from the EPC general contractors (B7) & $\mathrm{b} 7.1 ; \mathrm{b} 7.2 ; \mathrm{b} 7.3$ & 0.690 \\
\hline Consequences of risks (B8) & $\mathrm{b} 8.1 ; \mathrm{b} 8.2$ & 0.684 \\
\hline Calculation results of the sum of the variables & & 0.834 \\
\hline
\end{tabular}

The Cronbach's Alpha coefficient $\alpha>0.6$, which holds enough reliability to permit the use of the survey results[5]. After eliminating the unqualified variables, the results are as shown in the Table 4.

3)Calculate and analyze the discovery factors: Before performing the SEM model simulation, it is necessary to conduct the calculation and analysis of the discovery factors, investigate the main factors, including the observation variables (survey questions), and test the reliability as shown in Table 5. In the factor analysis of SPSS, the factor deduction method "Principal Axis Factoring" and the horizontal rotation method, Promax, were used.

Table 5: Pattern Matrixa

\begin{tabular}{|c|c|c|c|c|c|c|c|}
\hline \multirow{2}{*}{} & \multicolumn{7}{|c|}{ Factor } \\
\hline & 1 & 2 & 3 & 4 & 5 & 6 & 7 \\
\hline b1.2 & 0.710 & & & & & & \\
\hline b1.3 & 0.911 & & & & & & \\
\hline b2.1 & & 0.925 & & & & & \\
\hline b2.3 & & 0.642 & & & & & \\
\hline b3.1 & & & 0.851 & & & & \\
\hline b3.3 & & & 0.539 & & & & \\
\hline b3.4 & & & 0.605 & & & & \\
\hline b4.1 & & & & 0.811 & & & \\
\hline b4.3 & & & & 0.875 & & & \\
\hline b5.1 & & & & & 0.540 & & \\
\hline b5.3 & & & & & 0.660 & & \\
\hline b5.4 & & & & & 0.672 & & \\
\hline b6.1 & & & & & & 0.749 & \\
\hline b6.2 & & & & & & 0.911 & \\
\hline b7.1 & & & & & & & 0.500 \\
\hline b7.2 & & & & & & & 0.781 \\
\hline b7.3 & & & & & & & 0.685 \\
\hline
\end{tabular}

The results are required to obtain a KMO $>=0.5$ (Hair et al.., 2006)[7], testing coefficient with the statistical meaning Bartlett(Sig<0.05) (Hair et al.., 2006)[7]. . Additionally, each variable features the 
factor loading coefficient larger than 0.5; Jabnoun \& Al-Tamimi (2003)[8] providing that the factor loading coefficient of the variables is not less than 0.3, Gerbing \& Anderson (1988)[9] clarifies the percentage of variance higher than 50\%. Initially, the author used 18 variables, based on the standard of the factor loading coefficient larger than 0.5 . The author gradually deleted the variables b3.2, then the factors analysis was conducted. Seven factors were chosen, B1, B2, B3, B4, B5, B6, B7, whose percentage of variance reached $56.6 \%$, higher than the standard value of $50 \%$, as shown in the table 6 :

Table 6: KMO and Bartlett's Test、Total Variance Explained
\begin{tabular}{|c|c|r|}
\hline \multicolumn{3}{|c|}{ KMO and Bartlett's Test } \\
\hline $\begin{array}{c}\text { Kaiser-Meyer-Olkin Measure of } \\
\text { Sampling Adequacy. }\end{array}$ & 0.707 \\
\hline \multirow{2}{*}{$\begin{array}{c}\text { Bartlett's Test of } \\
\text { Sphericity }\end{array}$} & $\begin{array}{c}\text { Approx. } \\
\text { Chi-Square }\end{array}$ & 1262.739 \\
\cline { 2 - 3 } & df & 136 \\
\cline { 2 - 3 } & Sig. & 0.000 \\
\hline
\end{tabular}

The results shown in Table 6, the KMO test coefficient features the value of 0.707 ( $>0.5)$, and the coefficient with the Bartlett statistical meaning of ( $\operatorname{Sig}<0.05)$. This proves the survey results have reliability; the question hypotheses are reasonable; the survey data is proper, and objective. The data is sufficient for conducting analysis in the following steps:

Calculate and analyze the factors: The author used the AMOS software with the model of 7 hidden risk variables and 17 assumption risk variables found above to conduct the calculation, analysis and verification of the factors. The results show that the variables hypotheses are suitable for conducting the following analysis and assessment steps.

Analyze and verify the combination of factors: The author used the AMOS20.0 software for 8 assumption factors and 19 assumption risk variables to calculate the standardized factor loading coefficient of the 19 assumption risk variables in the interval of 0.501 to 1.092 (Table 7). In accordance with the standard factor loading coefficient $>0.5$, which shows the assumption risk variables for the groups of combined factors in a close relationship; the hypothesized risk variables have the largest effect on the factors group, as pointed out in the model.

After eliminating the hypothesized risks with the factor loading coefficients, the author calculated the reliability value of the CR combination of the minimum factor is 0.76 . All values are larger than the standard coefficient of 0.5[5], proving that the assumption variables compared with the assumption variables models is highly consistent. The author calculated the Average Variance Extracted, AVE, found the abnormal average values, and conducted the confirmation of convergence of assumption variables in the model. The result showed the AVE value in the interval of 0.51 to 0.74 , All values are larger than the standard coefficient of 0.5[10] proving the assumption variables compared with the factors with good convergence. (See Table 7) 
Table 7. Cronback's alpha, Avegare variance Extracted and AVE values

\begin{tabular}{|c|c|c|c|c|}
\hline The assumption variables & $\begin{array}{l}\text { Factor } \\
\text { loading } \\
\text { coefficients }\end{array}$ & $\begin{array}{l}\text { Errors of } \\
\text { variables }\end{array}$ & CR & AVE \\
\hline \multicolumn{5}{|l|}{ Risk from natural conditions and social environment (B1) } \\
\hline Geology, topography, and hydrography (b1.2) & & & 0.85 & 0.74 \\
\hline Transportation outside of the construction site (b1.3) & 0.897 & 0.147 & & \\
\hline Risk from management (B2) & 0.717 & 0.325 & \multirow{3}{*}{0.84} & \multirow{3}{*}{0.73} \\
\hline \multirow{2}{*}{ Poor progress management (b2.1) } & & & & \\
\hline & 0.957 & 0.092 & & \\
\hline Risk from techniques (B3) & 0.662 & 0.406 & \multirow{3}{*}{0.76} & \multirow{3}{*}{0.51} \\
\hline Technical design (b3.1) & & & & \\
\hline Construction drawings (b3.3) & 0.734 & 0.459 & & \\
\hline Inspection of technical and drawings design (3.4) & 0.717 & 0.487 & & \\
\hline Risk from contracts ( B4) & 0.676 & 0.516 & \multirow{3}{*}{0.81} & \multirow{3}{*}{0.68} \\
\hline Uncertain and unclear contract terms (b4.1) & & & & \\
\hline Transportation outside the construction site ( b4.3) & 0.925 & 0.175 & & \\
\hline Risk from economy (B5) & 0.767 & 0.518 & \multirow{3}{*}{0.77} & \multirow{3}{*}{0.53} \\
\hline Finances of the investor (b5.1) & & & & \\
\hline Risks on inflation (b5.3) & 0.818 & 0.222 & & \\
\hline Financial capacity of the contractors (b5.4) & 0.507 & 0.460 & & \\
\hline Risk from politics and law (B6) & 0.603 & 0.457 & \multirow[b]{2}{*}{0.84} & \multirow[b]{2}{*}{0.72} \\
\hline $\begin{array}{l}\text { The relationship of investor, general contractor with the } \\
\text { authority and relevant departments (b6.1) }\end{array}$ & & & & \\
\hline Laws and regulations of the management agencies (b6.2) & 0.847 & & & \\
\hline \multicolumn{5}{|l|}{ Risk from the EPC general contractors (B7) } \\
\hline $\begin{array}{l}\text { Purchasing materials, supplies, equipment.. (b7.1) } \\
\text { Sub-contractor (b7.2) }\end{array}$ & 0.812 & 0.276 & \multirow{2}{*}{0.80} & \multirow{2}{*}{0.58} \\
\hline Equipment installation and commissioning (b7.3) & 0743 & 0298 & & \\
\hline \multirow{4}{*}{$\begin{array}{l}\text { Consequences of the risk `actors(B8) } \\
\text { Prolong the construction progress (b8.1) } \\
\text { Increase construction costs (b8.2) }\end{array}$} & $\begin{array}{l}0.143 \\
0.721\end{array}$ & $\begin{array}{l}0.298 \\
0.391\end{array}$ & & \multirow{4}{*}{0.70} \\
\hline & 0.654 & 0.408 & \multirow{3}{*}{0.80} & \\
\hline & 1.092 & 0.047 & & \\
\hline & 0.501 & 0.576 & & \\
\hline
\end{tabular}

4)Confirm the model as pointed out:

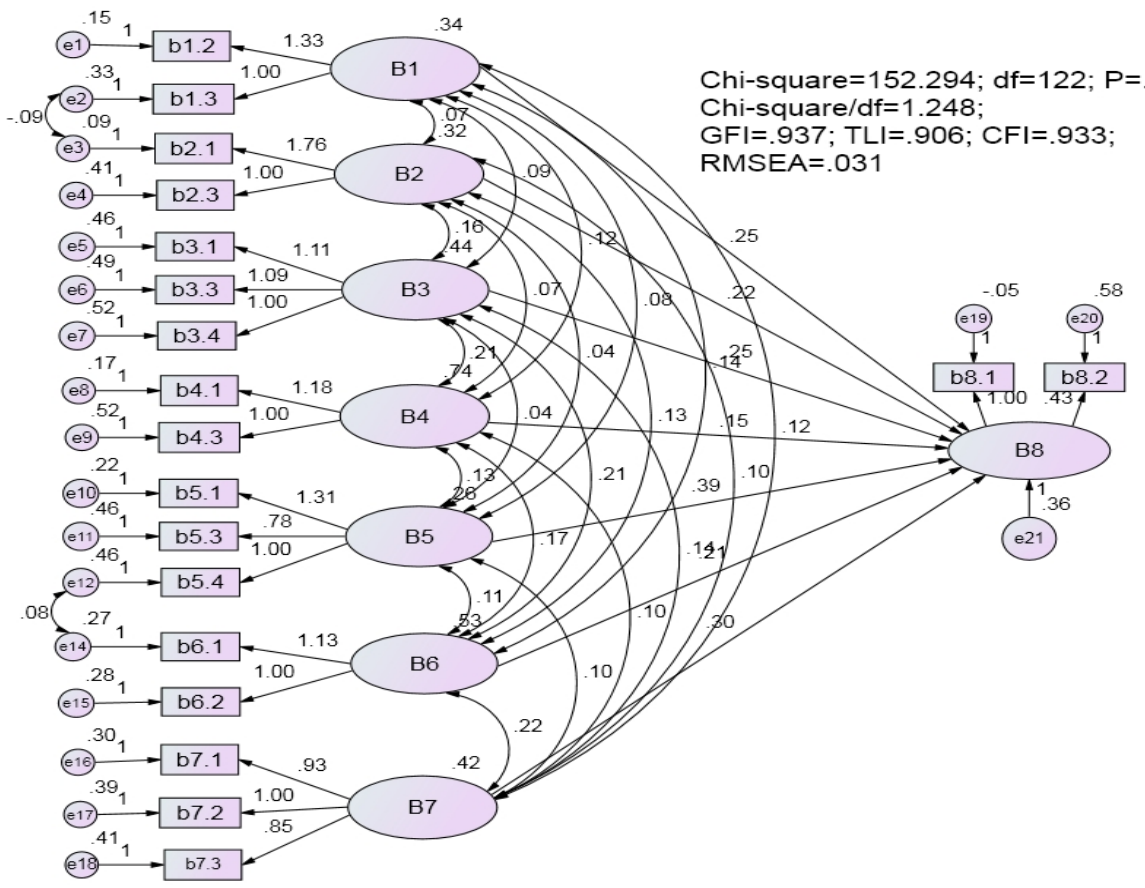

Fig. 2: The structure of SEM model and assessment result 
shown in the Figure 2 and from the following table 8, it is possible to conclude that the assessment result is extremely ideal; and further indicates the proposed model for the survey data is of reasonable design.

Table 8:Absolute appropriate index and Information index

\begin{tabular}{|c|c|c|c|c|c|}
\hline \multirow{2}{*}{} & \multicolumn{5}{|c|}{ Absolute appropriate index } \\
\cline { 2 - 6 } & \multicolumn{1}{|c|}{ Chi-square/df } & GFI & TLI & CFI & RMSEA \\
\hline Value & 1.248 & 0.937 & 0.906 & 0.933 & 0.031 \\
\hline \multirow{3}{*}{$\begin{array}{c}\text { Assessme } \\
\text { nt criteria }\end{array}$} & $\begin{array}{c}\text { Hair et al 1998 [5] } \\
\text { think that } \\
1<\text { chi-square/df }<3 \text { is }\end{array}$ & $\begin{array}{l}\text { Segar, } \\
\text { Grover,1993[11] and } \\
\text { Vhin, Todd, think } \\
\text { very good }\end{array}$ & $\begin{array}{l}\text { Taylor, } \\
\text { that }>0.9 \text { is very } \\
\text { good. }\end{array}$ & $\begin{array}{c}\text { Sharland,Cronin,Bullar } \\
\text { d,1993 [12] think that } \\
\text { RMSEA <0.05 is very } \\
\text { good }\end{array}$ \\
\hline
\end{tabular}

5)Review the parameters of the model: According to the parameters of the regression model given in Table 9, the values (p) of the assumption items are also less than 0.05 , which explains the reliability level of over $95 \%$. The risk factors strongly affected the extension of the construction progress.

Table 9. the values: C.R, P, Standardized coefficients

\begin{tabular}{|c|c|c|c|c|c|}
\hline Assumption & $\begin{array}{c}\text { Non- } \\
\text { standardized } \\
\text { coefficients }\end{array}$ & S.E. & C.R. & $\mathrm{P}$ & $\begin{array}{l}\text { Standardized } \\
\text { coefficients }\end{array}$ \\
\hline $\begin{array}{l}\text { Risk from economy (B5) } \rightarrow \text { Consequences of risks } \\
\text { (Extend the construction progress) }\end{array}$ & 0.386 & 0.121 & 3.198 & 0.001 & 0.215 \\
\hline $\begin{array}{l}\text { Risk from the EPC general contractors (B7) } \\
\longrightarrow \text { Consequences of risks (Extend the construction } \\
\text { progress) }\end{array}$ & 0.300 & 0.103 & 2.912 & 0.004 & 0.212 \\
\hline $\begin{array}{l}\text { Risk from techniques (B3) } \longrightarrow \text { consequences of risks } \\
\text { (Extend the construction progress) }\end{array}$ & 0.246 & 0.103 & 2.374 & 0.018 & 0.176 \\
\hline $\begin{array}{l}\text { Risk from politics and law (B6) Consequences of } \\
\text { risks (Extend the construction progress) }\end{array}$ & 0.214 & 0.088 & 2.435 & 0.015 & 0.170 \\
\hline $\begin{array}{l}\text { Risk from natural conditions and social environment } \\
\text { (B1) } \rightarrow \text { Consequences of risks (Extend the } \\
\text { construction progress) }\end{array}$ & 0.251 & 0.090 & 2.804 & 0.005 & 0.160 \\
\hline $\begin{array}{l}\text { Risk from management }(\mathrm{B} 2) \rightarrow \text { Consequences of } \\
\text { risks (Extend the construction progress) }\end{array}$ & 0.225 & 0.093 & 2.404 & 0.016 & 0.138 \\
\hline $\begin{array}{l}\text { Risk from contracts }(\mathrm{B} 4) \rightarrow \text { Consequences of risks } \\
\text { (Extend the construction progress) }\end{array}$ & 0.145 & 0.063 & 2.321 & 0.020 & 0.136 \\
\hline
\end{tabular}

Note:***Indicate the value less than 0.001

From the standardized coefficients values, it is found that the largest risk factor is Risk from the Economy (B5), which can severely delay the construction progress. The remaining factors from high to low impact level are: Risk from the EPC general contractors (B7); Risk from techniques (B3); Risk from the politics and law (B6) ; Risk from natural conditions and social environment (B1); Risk from the management (B2); Risk from contracts (B4).

\section{Risk control of EPC hydropower construction project in Vietnam}

The risk management of the project can be strengthened through the following:

(1) The contractors of the construction process must raise awareness about the danger of risks, identify and assessment of the risks and take appropriate measures to deal with the various predictable and avoidable risks.

(2) The general contractor should strengthen the cooperation with the relevant parties in communication, and information exchange related to prevent the loss of information due to poor communication and delays.

(3) The general contractors should research prior to the bidding stage, thorough analysis of the relevant provisions in the contract and risks responsibilities; the general contractors need to clearly understand the project information in the fields of the socio-politics, unforeseen circumstances, technical changes and inflation risk, etc. 
(4) The general contractors must enhance the detection of potential risks, The contractors need to be in constant communication with the investor and the relevant units to deal with any unexpected situations.

Under the proposal of the above risk control and restraint, the author suggests combined with the recommendations of the leading experts to control and restrain the risks, the author has obtained the following results shown in Table 10:

Table 10:Measures to restrain the risks affecting the construction progress

\begin{tabular}{|c|c|c|}
\hline $\begin{array}{c}\text { Risk group level } \\
1\end{array}$ & Risks level 2 & Measures to restrain the risks affecting the construction progress \\
\hline \multirow{3}{*}{$\begin{array}{l}\text { Risk from } \\
\text { economy } \\
\text { (B5) }\end{array}$} & $\begin{array}{l}\text { Risk from the } \\
\text { finance of the } \\
\text { investor (b5.1) }\end{array}$ & $\begin{array}{l}\text { The investor must be thoroughly checked by the government, in regard to } \\
\text { financial capacity, to ensure finances for construction. A guarantee from the } \\
\text { bank is required, for the off chance that the investor does not pay general } \\
\text { construction contractor as scheduled. }\end{array}$ \\
\hline & $\begin{array}{c}\text { Risks from } \\
\text { inflation (b5.3) }\end{array}$ & $\begin{array}{l}\text { For the bank loan contract and the international construction contract, the } \\
\text { contract value must be calculated in US dollars; the domestic subcontract is } \\
\text { calculated in local currency and adjustment under the inflation rate of the } \\
\text { market. }\end{array}$ \\
\hline & $\begin{array}{l}\text { Risks from the } \\
\text { financial capacity } \\
\text { of the EPC general } \\
\text { contractors (b5.4) }\end{array}$ & $\begin{array}{l}\text { The EPC general contractors must provide financial backing for the } \\
\text { construction on a set schedule, and must have a bank guarantee; the bank } \\
\text { should pay the necessary amounts that the general contractor is unable to pay } \\
\text { for subcontractors }\end{array}$ \\
\hline \multirow{3}{*}{$\begin{array}{l}\text { Risk from the } \\
\text { EPC general } \\
\text { contractors } \\
\quad \text { (B7) }\end{array}$} & $\begin{array}{l}\text { Risk from } \\
\text { purchasing } \\
\text { materials, supplies, } \\
\text { equipment and } \\
\text { machines (b7.1) }\end{array}$ & $\begin{array}{l}\text { It is required to purchase and manufacture goods on a set schedule to serve } \\
\text { the projects, specifically the goods which are unavailable in the host country } \\
\text { and must be imported; Commodity purchase contracts of EPC contractor and } \\
\text { subcontractors must be clear in terms of reward and punishment for slow } \\
\text { supply of goods. } \\
\text { The Government must have the directions and create favorable conditions } \\
\text { for the import of goods for projects. }\end{array}$ \\
\hline & $\begin{array}{l}\text { Risk from the } \\
\text { sub-contractor } \\
\text { (b7.2) }\end{array}$ & $\begin{array}{l}\text { The subcontracts must have substantial construction capacity. } \\
\text { The subcontracts must have the financial capacity to carry out the project } \\
\text { and a bank guarantee; Economic contract of EPC contractors and } \\
\text { subcontractors must be fixed, clear, and have strict reward or punishment for } \\
\text { progress. }\end{array}$ \\
\hline & $\begin{array}{l}\text { Risk from } \\
\text { equipment } \\
\text { installation and } \\
\text { commissioning } \\
\quad \text { (b7.3) }\end{array}$ & $\begin{array}{l}\text { The production equipment must be on par with international standards; The } \\
\text { equipment installation company must be highly qualified; The equipment } \\
\text { manufacturing company must have professional technicians guiding the } \\
\text { machines, equipment installation, and commissioning; The general contract } \\
\text { and subcontractors' equipment installation contract must be clear and strict } \\
\text { in terms of payoff for the slow progress. }\end{array}$ \\
\hline \multirow[t]{2}{*}{$\begin{array}{l}\text { Risk from } \\
\text { techniques } \\
\text { (B3) }\end{array}$} & $\begin{array}{l}\text { Risk from the } \\
\text { technical design } \\
\text { (b3.1); Risks of } \\
\text { construction } \\
\text { drawings (b3.3) }\end{array}$ & $\begin{array}{l}\text { The technical and construction draft design must be assigned to capable } \\
\text { units having implemented the design of equivalent works or of construction } \\
\text { larger scale. The design must comply with the work scale as approved by the } \\
\text { investor and the authorities. } \\
\text { Design changes must be attached with the legal documents of the investor, } \\
\text { and must have the contract price adjustment equivalent to the content and } \\
\text { changes in work volume; The general contractors' design contracts with the } \\
\text { design company must be clear, and make known that there will be strict } \\
\text { payoff for slow progress. }\end{array}$ \\
\hline & $\begin{array}{l}\text { Risk from the } \\
\text { inspection of } \\
\text { technical and } \\
\text { drawings design } \\
\text { (b3.4) }\end{array}$ & $\begin{array}{l}\text { The technical design inspection is assigned to the a company, having } \\
\text { implemented an equivalent project or of projects of larger scale; The } \\
\text { inspection must implement in detail of the design drawings of the technical } \\
\text { and construction design documents. }\end{array}$ \\
\hline
\end{tabular}




\begin{tabular}{|c|c|c|}
\hline \multirow{2}{*}{$\begin{array}{l}\text { Risk from } \\
\text { politics and law } \\
\text { (B6) }\end{array}$} & $\begin{array}{l}\text { The relationship of } \\
\text { investor, general } \\
\text { contractor with the } \\
\text { authority and } \\
\text { relevant } \\
\text { departments (b6.1) }\end{array}$ & $\begin{array}{l}\text { The investor and contractors must work together with the local authorities to } \\
\text { ensure the tasks relating to the project run smoothly. } \\
\text { The investor and contractors must have a good relationship with the relevant } \\
\text { departments to efficiently implement the regulations relating to the project, } \\
\text { such as protecting the environment, electricity sales, connecting power to the } \\
\text { national electric network system, etc. }\end{array}$ \\
\hline & $\begin{array}{l}\text { Risk from laws and } \\
\text { regulations of the } \\
\text { management } \\
\text { agencies (b6.2) }\end{array}$ & $\begin{array}{l}\text { The investor and contractors must have a thorough understanding of the law } \\
\text { and all relevant regulations. } \\
\text { The investor and contractors must have a professional legal committee to } \\
\text { assist in researching the legal applications and regulations of the authorities } \\
\text { and the relevant departments. }\end{array}$ \\
\hline \multirow[t]{2}{*}{$\begin{array}{l}\text { Risk from } \\
\text { natural } \\
\text { conditions and } \\
\text { social } \\
\text { environment } \\
\quad \text { (B1) }\end{array}$} & $\begin{array}{l}\text { Risk from geology, } \\
\text { topography, and } \\
\text { hydrography (b1.2) }\end{array}$ & $\begin{array}{l}\text { An experienced monitoring unit, with an equivalent scale or larger, must be } \\
\text { appointed. The investor and survey document designing unit shall appoint } \\
\text { qualified and skilled staff. It is required to obtain an independent inspection } \\
\text { unit to detect errors in survey results on a set schedule } \\
\text { The monitoring unit, in addition to the investor, and general contractor must } \\
\text { supervise the environmental conditions during the construction process, and } \\
\text { furthermore take measures to allow prompt response to any unforeseen } \\
\text { issues that may arise. }\end{array}$ \\
\hline & $\begin{array}{l}\text { Risk from } \\
\text { transportation } \\
\text { outside the } \\
\text { construction site } \\
\quad \text { (b1.3) }\end{array}$ & $\begin{array}{l}\text { The investor must invest to upgrade and maintain the necessary roads } \\
\text { surrounding the construction site to ensure safe transport of equipment to } \\
\text { and from the construction site. }\end{array}$ \\
\hline \multirow{2}{*}{$\begin{array}{l}\text { Risk from } \\
\text { management } \\
\quad \text { (B2) }\end{array}$} & $\begin{array}{l}\text { Risk from the poor } \\
\text { progress } \\
\text { management (b2.1) }\end{array}$ & $\begin{array}{l}\text { The general contractor and subcontractors must continuously monitor each } \\
\text { individual part of the construction progress, to ensure all parts are working } \\
\text { correctly and efficiently to minimize any possible delay. }\end{array}$ \\
\hline & $\begin{array}{l}\text { Risk from the } \\
\text { construction items } \\
\text { monitoring unit } \\
\text { (b2.3) }\end{array}$ & $\begin{array}{l}\text { The construction supervision contract must be assigned to capable units, } \\
\text { having already implemented similar projects or of large scale; The } \\
\text { supervisors must be skillful in all aspects of the project, and continuously } \\
\text { monitor all aspects of the construction. }\end{array}$ \\
\hline \multirow{2}{*}{$\begin{array}{l}\text { Risk from } \\
\text { contracts } \\
\text { (B4) }\end{array}$} & $\begin{array}{l}\text { Risk from uncertain } \\
\text { and unclear } \\
\text { contract terms (4.1) }\end{array}$ & $\begin{array}{l}\text { The contract terms must be precise and clear, the contract language must be } \\
\text { consistent, and must have an appendix explaining any terms potentially } \\
\text { considered difficult, in order to avoid any disputes. }\end{array}$ \\
\hline & $\begin{array}{l}\text { Risk on fixing the } \\
\text { EPC contract price } \\
\text { (b4.3) }\end{array}$ & $\begin{array}{l}\text { The EPC hydropower contracts typically set the cost, so the risks are borne } \\
\text { by contractors; thus, a contract appendix for price adjustment is required, in } \\
\text { the event of force majeure that increases the cost of construction. }\end{array}$ \\
\hline
\end{tabular}

\section{Conclusions}

The work achieved includes the following:

(1) Recognizing the risks existing in the EPC hydropower projects in Vietnam, thereby establishing the risk factor model for projects in Vietnam.

(2) Based on those risk models, calculating, analyzing and carefully evaluating the risks to determine the 17 the main reason causes leading to the delays of construction progress of the projects.

(3) Discovering the levels of risk impacts to construction progress, found that the largest risk factor is Risk from the Economy (B5), which can severely delay the construction progress. The remaining factors from high to low impact level are: Risk from the EPC general contractors (B7); Risk from techniques (B3); Risk from the politics and law (B6) ; Risk from natural conditions and social environment (B1); Risk from the management (B2); Risk from contracts (B4). 
(4) suggesting measures to control and appropriately restrain the risks. Thus, helping the investor and the EPC general contractors to understand and become more aware of the risks, allow for more efficient implementation, and easier risk control.

These efforts have achieved the goals set by the original thesis: Risk evaluation and control of EPC hydropower construction project in Vietnam.

\section{References}

[1] ZHAOJuelong: A Brief Study on the Risk Management of the Vietuamese Hydro Power Project Contract.Enterprise Science And Technology \& Development Press, 20(2008): pp. $42-45$

[2] LI wei: Study on the Risk Management for International Hydropower Engineering of EPC Program . Dalian:Dalian Universityof Technolog. 2012

[3] Jixin Wei and Liujian Zhe ..: The whole process of overseas engineering project risk management. International Economic Press, 8 (2013), pp. 77-81

[4] Zhao shan: Study of p. management for the Kamchay Hydropower Station". Xian, NorthwestUniversity, 2013

[5] Hair J F, Anderson R E, Tatham R L, etal: Multivariate Data Analysis. UpperSaddleRiver, New jesay, Prentice Hall , 34(1998), pp. 78-82

[6] Slater S: Issues in Conducting Marketing Strategy Research. Journal of Strategic, 5(1995): pp. 147-151

[7] J. Hair et al..: Multivariate data analysis, New Jersey: Prentical Hall. 2006

[8] Jabnoun and Al-Tamimi: Measuring perceived service quality at UAE commercial banks, International Journal of Quality and Reliability Management. (2003), pp. 47-55

[9] Gerbing and Anderson: An Update Paradigm for Scale Development Incorporing Unidimensionality and Its Assessments, Journal of Marketing Research. (1988) , pp. 36-45

[10] Fornell C, Larcker D F: Evaluating structural equation models with unobservable variables and measurement er-ror. Journal of Marketing Research, ,18 (1981), pp. 39-50

[11] Segars, A. H., and Grover, V..: Re-examining Perceived Ease of Use and Usefulness: A Confirmatory Factor Analysis, MIS Quarterly 17:4 (1993), pp. 517-525.

[12] Taylor, S., A. Sharland, J. Cronin and W. Bullard: Recreational Service Quality in the International Setting, International Journal of Service Industry Management, 4:4 (1993), pp. $68-86$

[13] Pterson R: A Meta-Analysis of Cronbach's Coefficient Alpha. Journal of Consumer Rsearch, 21(1994): pp. 38-91.

[14] Steenkam J-BEM và vantrijp: The use of LISREL in validating marketing constructs, Internatonal Journal of Research in Marketing .8 (1991), pp. 283- 299 